\title{
Sparring Partners: Fraternal Relations in the Homeric Hymn to Hermes
}

Sparring partners in the boxing ring engage in an apparent conflict, really governed by consensus and co-operation; all too many partnerships descend into sparring. My title thus aims to encapsulate two senses in which conflict and consensus can be related, both of which are pertinent to the Homeric Hymns to Hermes. The narrative possibilities of a shift from consensus to conflict and vice versa (as in the Hymn) are familiar from countless stories. The first three sections of this chapter analyse how the hymnist presents the origin of the conflict between Hermes and Apollo, the remarkably wide range of strategies for conflict-resolution which the two parties attempt, and the dynamics of the final movement beyond reconciliation to affection. We will see that the hymn engages closely with a range of emotional characteristics of ancient interpersonal conflict-resolution, and also with some of the technicalities of interstate reconciliations. The final section of the essay considers why the hymnist shaped the myth in this particular way for his performance. The gods' fraught relationship, as it develops through the narrative, not only allows for an inventive and performatively effective characterisation of Hermes, combined with the emphatic assertion of his friendship with Apollo. I shall argue that the other sense of 'sparring partners' also has an important role to play in the poetic logic of the gods' fraternising: it points to an intertextual relationship where the Hymn to Hermes spars with its own 'elder brother', the Homeric Hymn to Apollo - landing a few blows, but never intending a knock-out.

\section{THE ORIGIN OF THE CONFLICT}

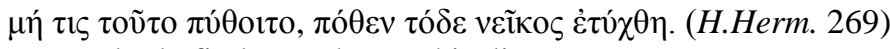
May nobody find out whence this dispute arose.

So Hermes, pretending to be selflessly advising Apollo: the latter's allegation that an infant has trekked

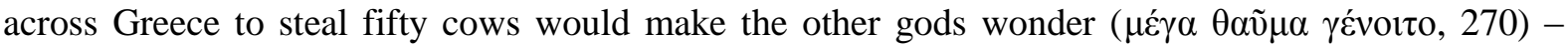
wonder, that is, about Apollo's sanity. But Hermes' words also underline for the external audience that they should wonder, at Hermes' precocity, since they have been given the materials to interpret 'whence 
the dispute arose'. On one level the answer is straightforward: the origin is Hermes' theft of Apollo's cows. But Hermes abhors the straightforward. The theft itself has an origin, in Hermes' mind, and it is the hymn's enigmatic presentation of that with which the interpreter must start.

The first mental disposition attributed to Hermes in the hymn's narrative comes in lines 21-2:

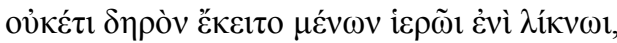

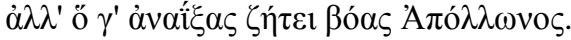

He did not continue lying down and stay for long in his sacred winnowing-fan cradle: he leapt up and began to seek Apollo's cows.

For the moment, this desire is left unexplained - a child's whimsy. It is also held in suspense: Hermes immediately gets distracted from his search, by finding a tortoise on the threshold and creating a lyre out of it. The thread then resumes with new information at lines 64-6:

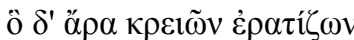

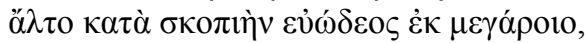

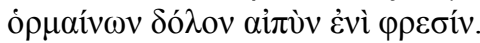 \\ He, lusting for meat, jumped out of the sweet-smelling hall to look around, an impulse to sheer trickery \\ in his mind.
}

Hermes' hunger is introduced curtly and vigorously, by reapplying an Iliadic description of a lion's

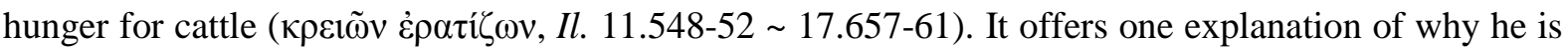
after the cows. Like whimsy before it, so here the bestial and unmediated desire for food suits a baby. ${ }^{2}$

Hermes steals fifty cows, takes them to a meadow by the river Alpheus, and cooks two of them. In the event, the social norm that gods avoid meat kicks in and he refrains from eating, despite temptation. ${ }^{3}$ Particularly revealing for our purposes are lines 128-9, the description of Hermes' carving:

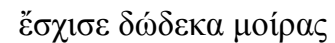

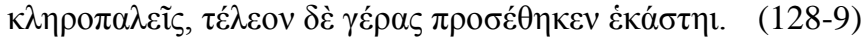

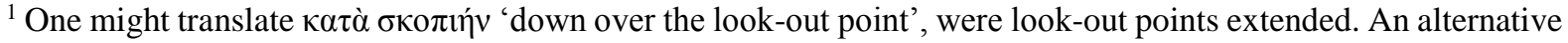

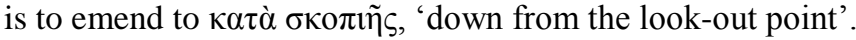

${ }^{2}$ Cf. Renehan 1981: 241 for Plato on children's lack of $\lambda$ ó ${ }^{\circ} \varsigma$ as a motivating factor (esp. Leg. 7 808d); Arist. EN

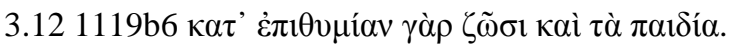

${ }^{3}$ At 64 he 'lusted for meat', whereas at 130 he 'desired the right to eat the meat' (órí + gen., as in LSS 115 A.215; cf. Parker 1983: 336-9). Though his impulse intensifies at the smell, a sense of propriety has intervened, 'nor was his $\theta 0 \mu$ ó $\varsigma$ persuaded' (132) to eat.
} 
He split twelve portions to be assigned by ballot, and added a perfect honorific portion to each.

This action, at least, is not motivated purely by hunger: Hermes is not intending to recombine these carefully separated portions in his own stomach, nor is he expecting any fellow guests, since he is acting in secret well before breakfast. Rather, the twelve equal portions symbolise Hermes' ambition of equal rank within a Dodecatheon-cult. ${ }^{4}$

This ambition, at first implicit, emerges from its shell when Hermes gets home and answers a telling-off from his mother. Maia knows, with maternal intuition, that Apollo is the victim of Hermes' activities; she threatens that he will come and get Hermes, and also despairs that Hermes may become a mountain brigand (155-61). After impudently professing not to be at all cowed by this rebuke (1635), Hermes defends himself as follows:

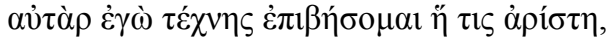

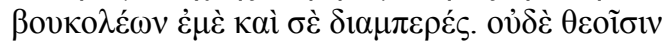

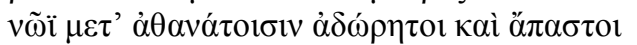

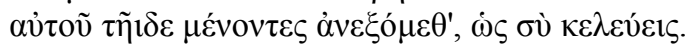

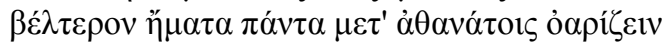

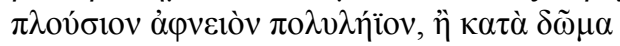

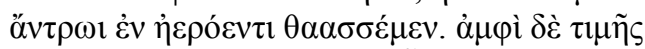

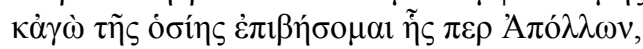

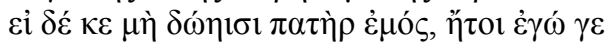

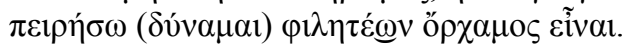

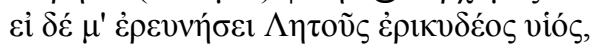

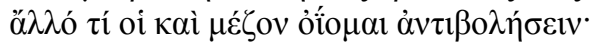

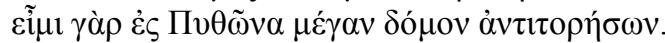

$I$ shall embark on whatever skill is best, shepherding you and me continually. Nor will we two among the immortal gods endure without gifts or food by just staying here, as you urge. Better to chat with the immortals for all one's days, rich, wealthy and with plenty of spoils, than to sit at home in a murky cave. For the sake of honour, I too will embark on just the same proper behaviour as Apollo, but if my father withholds it, then I tell you I shall try (I am able!) to be the chief of brigands. And if the son of glorious Leto shall search for me, I rather think another, more major business will meet with him: I shall go to Pytho to pierce into his great house.
\end{abstract}

The symbolism of his carving is made explicit. Hermes' ambition is to get out of the cave and up to Olympus, to get the same level of $\tau \imath \mu$ as Apollo by Zeus's dispensation (174); he applies the threat of otherwise becoming a criminal mastermind, and in particular opposing Apollo if he gets caught out in

\footnotetext{
${ }^{4}$ Regarding Greek cults for groups of twelve gods, see Long 1987. The hymn is engaging here with an earlier literary conflict, Prometheus' jealous carving against Zeus in the Theogony: see e.g. Kahn 1978: 51-60 (caution required), Sowa 1984: 198-211.
} 
this case. The two courses - the prerogative of becoming a cow-herd, and the use of deception - are

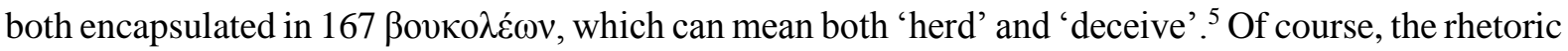
cannot be taken wholly seriously: an ancient audience would have struggled to conceptualise a cosmic guerrilla causing havoc for long under Zeus' regime. The infant Hermes is not yet politically astute or realistic. Nevertheless, his is a threat which has to be managed, and the way Zeus and Apollo do deal with it on one (not terribly serious) level 'explains' the moderate contemporary crime-rate. ${ }^{6}$

The end of Hermes' speech is a major juncture-point in the hymn, from where we can review his thought-process. Successively the hymn prompted the schemas 'babyish lack of motivation' and 'babyish motivation' (hunger) before giving a symbol of Hermes' actual motivation (his carving), and finally a statement of it. The underlying motive is ambition, specifically the envy of a younger halfbrother at the status of an older. The cattle-theft stakes a claim to patronage of cow-herding against Apollo, and simultaneously provides initial evidence that Hermes is worth keeping on-side. At some point the Olympians will have to take notice and enter into bargaining. ${ }^{7}$

A further detail from Hermes' initial address to the tortoise acquires new sense against this background:

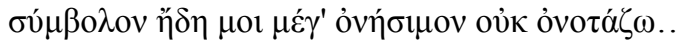

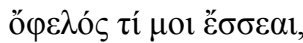

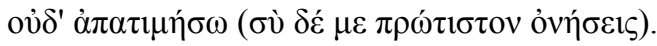
This sign I've encountered, which is instantly very beneficial, I do not disparage. ... You will be a help for me, and I will not completely dishonour you - for you will be the first to benefit me.

The triple emphasis on the tortoise's benefits suggests not just the pleasantness of future lyre-music, but its utility in bargaining with Apollo, which Hermes already foresees.

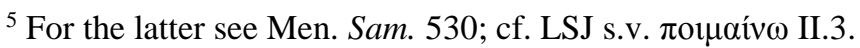

${ }^{6}$ Though Hermes acquires the $\gamma \varepsilon \dot{\varepsilon} \rho \alpha \varsigma$ of being a 'prince of thieves' (291-2), and the hymn ends with a rather disturbing focus on his 'continual deception' of his worshippers (577), the situation where he organizes a network of militant criminals has been avoided.

${ }^{7}$ The hymnist sets up the plot so that all Olympians are involved, in that he presents Apollo as a prince herding

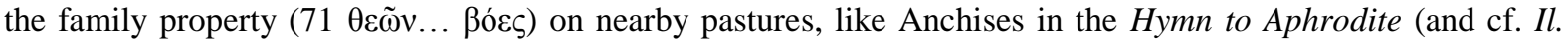
20.188-9, Od. 13.222-3). Elsewhere the cows belong to Admetos ( $\Sigma$ Nic. Alex. 560a; implicitly Ov. Met. 2.67686).
} 
I will return at the end of this chapter to why Hermes' thoughts are not immediately spelled out. For now I want to outline how the hymnist develops the quarrel when Hermes and Apollo meet.

\section{CONFLICT ABOUT CONFLICT-RESOLUTION}

At the end of Hermes' speech (181), prospects for his relationship with Apollo are not good. Maia threatened that Apollo would bind Hermes and carry him off (155-61). While several gods suffer binding in early Greek epic, the context in this passage and the reference to carrying Hermes off perhaps allude specifically to a criminal procedure like Athenian apagoge. ${ }^{8}$ Hermes counter-threatened escalation - to burgle Delphi if Apollo comes enquiring.

Hermes' rhetoric may be shown up as braggadocio when Apollo does indeed arrive, for then his gambit is quite different - to act infantile (237-42) and deny the crime. Or perhaps he thinks on his back and realises that he needs a more immediate strategy than threatening future burglary. Meanwhile Apollo chooses self-help and a show of force beyond even Maia's prediction. First he conducts a housesearch on Maia's cave. In Athenian terms (and we lack evidence about other places), he should formally request entry and remove his cloak. ${ }^{9}$ But Apollo just sweeps in, angry and imperious. He then threatens Hermes in 254-6:

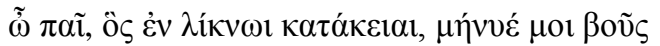

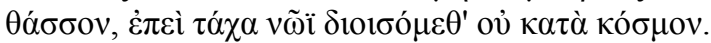

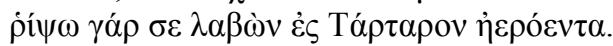

Boy, you lying in the winnowing-fan cradle, give me information about my cows, quick - since soon we will differ, against the order of things. I will seize you and fling you to murky Tartarus.

The lines are written for a threatening performance, with thunderous opening monosyllables, reprised at the end of 254 with a rare sixth-foot caesura, the enjambment of $\theta \dot{\alpha} \sigma \sigma o v$, the menacing litotes of $\tau \dot{\alpha} \chi \alpha$

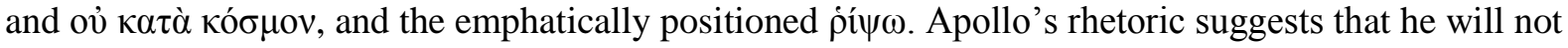
be content to haul Hermes off to a magistrate, but that he will appropriate Zeus's role of Tartarizing

\footnotetext{
${ }^{8} \dot{\alpha} \pi \alpha \gamma \omega \gamma \eta \dot{n}$, however, seems only to have been used against thieves caught in the act: Hansen 1976: 36-53, Cohen 1983: 34-92.

${ }^{9}$ For Athenian principles see Ar. Nu. $499+\Sigma$, Isaeus 6.42, Glotz 1904: 201-8.
} 
evil. ${ }^{10}$ However, such purely mythological systems of justice are tempered by Apollo's use of $\mu \eta v v ́ \omega$, which Hermes twists in 264 to the concept of a $\mu \eta ์ v v \tau \rho o v$, a 'reward for information'. This is a rare, highly technical word from real-life practice, and primes us for the other technical language of legal processes which will follow. ${ }^{11}$

Hermes moves on from the physical trick of making himself look like a sleepy baby to attempt resolution through cheeky debate. How could he, a mere baby, have stolen cows? This is probably the earliest extant argument from عikós, and thus a fairly cutting-edge forensic trope. ${ }^{12}$ But the argument's very ingenuity refutes it - this is no 'mere baby' talking. It is largely this paradoxical, self-refuting nature of Hermes' trickery which leads to a change in Apollo. He gives a gentle laugh (281). ${ }^{13}$ But we are still far from resolution, and Apollo hoicks Hermes out of his cot. Apollo has softened only as far as Maia's earlier prediction of an apagoge-like procedure; his threats are still severe, though now they lurk under the surface of his language:

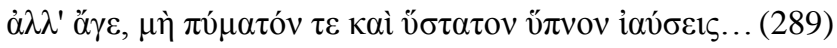

But come - lest you lie for your last and final sleep...

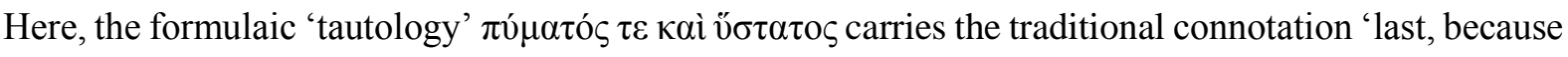
death intervenes' - a touch of hyperbolic bluster when turned against an immortal. ${ }^{14}$

Hermes responds to this speech even more ridiculously: he deliberately farts and sneezes. Rather than seeing Hermes as having a specific communicative goal, I would see him as posing Apollo an open-ended puzzle with these 'signs'. Apollo eagerly takes the opportunity to impose an interpretation, but thereby becomes complicit in the hermeneutic game. The gestures therefore bring

\footnotetext{
${ }^{10}$ This role belongs preponderantly to Zeus, though Athena sends Enceladus to Tartarus at E. HF 908, and Underworld powers send people down at [Hes.] Sc. 255, E. Or. 265.

${ }^{11}$ In classical sources, $\mu \eta ́ v v \tau \rho o v$ is used here and perhaps (derivatively) S. Ichn. $87 \mu \eta v v[$, and five times with reference to the mutilation of the Herms. At its prior use in Hipponax fr. 102.4 West, the context is unclear.

${ }^{12}$ Cf. Görgemanns 1976: 115-19.

${ }^{13}$ Compare the tone of Athena's laugh when she see through Odysseus' pretence at $O d .13 .287$.

${ }^{14}$ The other uses are Il. 22.203, Od. 4.685, 20.13, 20.116.
} 
him down another notch - literally in that he now sits down (299), and in that his interpretation is witty (301-3):

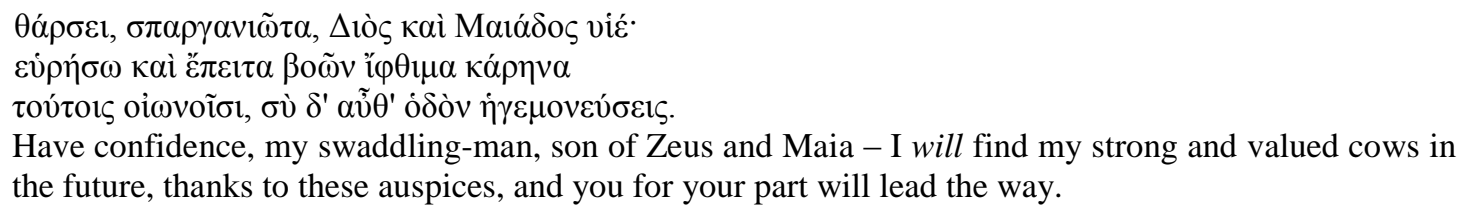

The tone can be seen from the silly ad hoc invention $\sigma \pi \alpha \rho \gamma \alpha v i \tilde{\omega} \tau \alpha$ and the self-deprecating joke that these 'auspices' will help, in contrast to the bird-omen at 213 which did not lead him to the cows. ${ }^{15}$ In Apollo's tendentious 'decoding' of the 'auspices', Hermes can be cheerful because he will be a leader... but he will lead Apollo to the cows, which is precisely what he does not want yet.

Hermes has, whether he strictly intended to or not, largely defused the situation, and now picks up on the hints which he had dropped earlier:

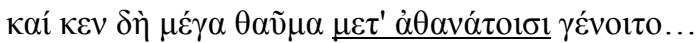

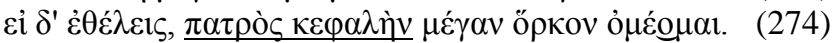

To be sure, it would be a great source of amazement among the immortals... If you want, I shall swear a great oath on my father's head.

Hermes' denials might, superficially, imply his desire to keep the cows for himself. But as the underlined phrases show, they increasingly have the ulterior motive of getting the matter referred to Zeus, and thus getting an introduction to Olympus. ${ }^{16}$ An explicit suggestion follows at 312 :

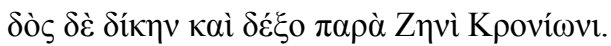

Agree to arbitration before Zeus son of Kronos.

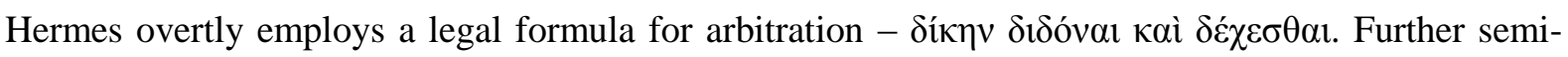
technical terms follow: according to the following line they debated $\delta 1 \alpha \rho \rho \eta \dot{\delta} \eta v$ ('in detail'); in 316,

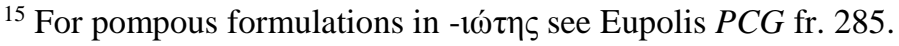

${ }^{16}$ A god's introduction to Olympus also occurs in H.Hom. 6.15, H.Pan 45, Hes. Th. 68. For a god's reintroduction see H.Dem. 484, West 2001 on H.Hom. 1.
} 


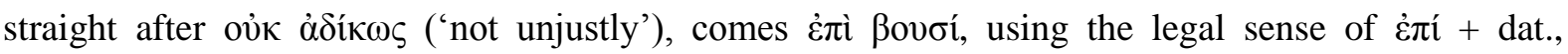
'concerning a charge of'. ${ }^{17}$

The arbitration-scene that follows is not replicated in any other version of the myth, but fits the hymnist's specific interests in shaping this poem. ${ }^{18}$ Forensic language continues to loom large, in the two highly rhetorical speeches which dominate the scene. Apollo makes an argument out of a human witness, who conveniently cannot make a deposition on Olympus which would reveal how much Apollo overplays his information. ${ }^{19}$ Hermes' defence basically follows the four-part structure enjoined by classical rhetorical theory: proem with ethopoiia (368-9), diegesis (370-5), argument (mainly 376-7), emotive epilogue (378-86). He repeats the forensic tropes of cikós-argument and informal oath-offer, but also launches a procedural counter-accusation:

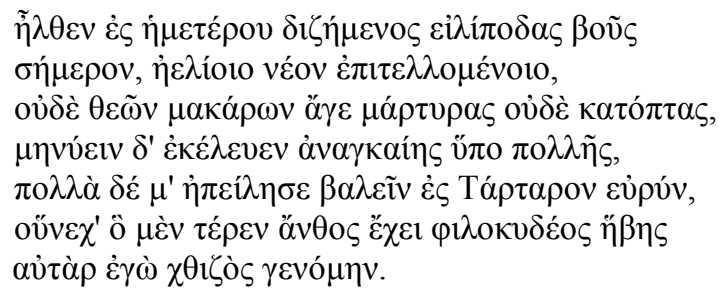

He came to our house today soon after the sun began to rise, in search of his shambling cows. He brought neither witnesses nor observers from among the blessed gods, and he ordered me to give information under much compulsion, and repeatedly threatened to throw me into broad Tartarus - all because he has the soft flower of ambitious youth, whereas I was born yesterday.

Apollo's house-search was illegal bullying because he did not bring divine witnesses (or indeed any, but only deities would be sufficiently reliable here), and perhaps also because he did it before visiting-

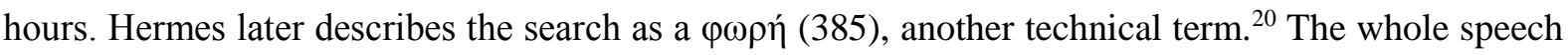

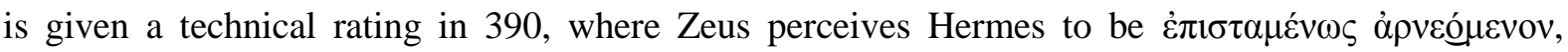

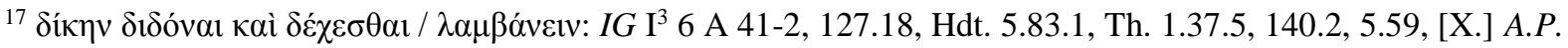
1.18, D. 53.20 (involving Athenians only; the others involve more than one polis). Early distribution of $\delta 1 \alpha \rho \rho \eta ์ \delta \eta v$, other than here: Andocides x1, Lysias x7, Isocrates x2, Isaeus x10, Plato x7 (all Lg.). غ̇ंí: LSJ s.v. B III.1.

${ }^{18}$ Roebuck 2001: 91-2 situates this scene within Greek arbitration practices, though very cursorily.

${ }^{19}$ In 340 Apollo neglects to mention that Hermes had only stolen a part of his herd; at 354-5 he neglects to mention that the witness was nowhere near Pylos, and uses vagueness to suggest that the witness had declared where Hermes was heading, whereas in fact his advice was very cautious (208-11) and did not help Apollo. For the opposition of evidence from a witness who cannot appear to a defendant's argument from cícós, cf. E. Hipp. 8851101, Antiphon T1, Arist. Rhet. 1376a17-23.

${ }^{20}$ Cf. LSJ s.v. $\varphi \omega \rho \alpha ́ \omega$.
} 
'making a skilled denial'. Zeus's own arbitration caps the scene's concern with legal language: he

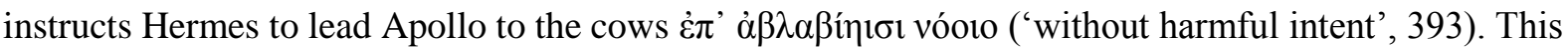
evokes classical legal formulas applied especially to how the parties to alliance agreements should treat each other $\dot{\alpha} \beta \lambda \alpha \beta \tilde{\omega} \varsigma \kappa \alpha \grave{\alpha} \delta \delta$ ó $\omega \varsigma$, 'avoiding harm and deceit'. ${ }^{21}$

What we see in this portion of the hymn is therefore not just conflict but also conflicting strategies adopted by the parties, as their initially entrenched views gradually soften. After Hermes' initial threat of retaliation, he adopted cunning and (unintentionally?) amusing forensic rhetoric to face Apollo's litigious house-search and threats of violence. Humour brought Apollo to a less vehement threat and a model close to apagoge. Further humour, this time deliberate from both sides, induced an agreement to arbitration before Zeus. ${ }^{22}$ The whole process is presented linguistically not just as two brothers agreeing to call on daddy, but via technical juridical terms as a public arbitration with many witnesses before an unbiased king - indeed, before the source of cosmic justice. ${ }^{23}$ The dispute's public nature is crucial given what we saw in the first section of this chapter about Hermes' longstanding desire for an introduction to divine society.

It may seem surprising that either Hermes or Apollo would be satisfied with Zeus's decision: Hermes does not get to keep the cows, and Apollo does not see Hermes punished. Again, humour plays a key conciliatory role. In lines 389-90, Zeus finds Hermes' defence hilarious:

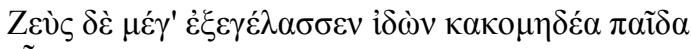

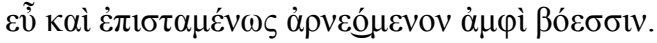
But Zeus laughed out loud when he saw his scheming son making a good skilful denial concerning the cows.
}

But Zeus himself had set things off on this track when he welcomed the pair to Olympus at 330-2:

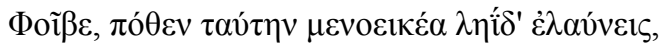

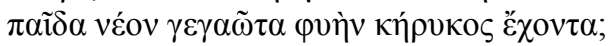

\footnotetext{
${ }^{21}$ See $I G \mathrm{I}^{3}$ s.v. $\dot{\alpha} \beta \lambda \alpha \beta-$, Th. 5.18, SEG XXIX 405b.6 (Olympia, $4^{\text {th }}$ C), TAM ii.1183.3 (Phaselis, $4^{\text {th }}$ C).

${ }^{22}$ The underlying categories here - retaliation, litigation, arbitration, discussion - are nothing special to H.Herm. Largely the same spectrum appears in Thucydides' seminal account of the public conflict on Corcyra in 427 (3.6981): private discussions, public debate, litigation (first acquittal, then capital punishment), assassination (then diplomacy which fails - the time for it is past), widespread massacre and war.

${ }^{23}$ On the characterisation of the Olympians as partly a family and partly political, see Graziosi's chapter.
} 


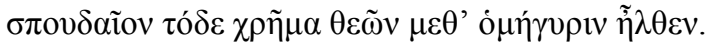

Phoebus, where are you driving this heart-warming booty from, a newly-born child with the natural body of a herald? This is a serious item which has come before the assembly of the gods!

Zeus's irony in accusing Apollo of 'driving booty' is obvious. To his credit Apollo accepts the lighthearted tone, beginning with puns:

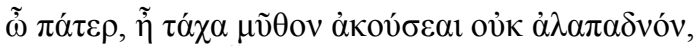

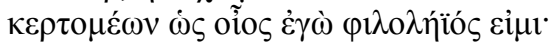

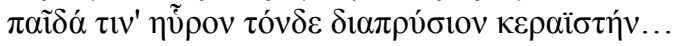

Father, soon, I tell you, you will hear a tale which is not stripped of force, though now you tease me that I am the only fan of booty: I found a child, as you see, a wide-ranging pillager..

$\dot{\alpha} \lambda \alpha \pi \alpha \delta v o ́ v$ (which I have translated 'stripped of force') is derived from $\dot{\alpha} \lambda \alpha \pi \alpha ́ \zeta \omega$, 'to empty a city by sacking it' and taking booty. Apollo copies Zeus's structure of a line beginning $\pi \alpha \tilde{\imath} \delta \alpha$, but adds very different predicates. $\delta 1 \alpha \pi \rho v ́ \sigma ı \varsigma$ ('far-reaching') normally qualifies noises, including the sound of a

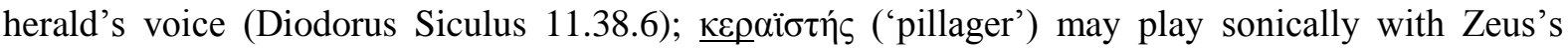

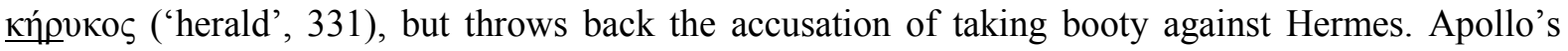
speech also ends for laughs with a near-verbatim quotation of Hermes' babyish denials, presumably performed in a suitably high-pitched and pleading voice. ${ }^{24}$

In other versions of the story Hermes' ability to make Apollo laugh is sufficient for reconciliation:

\section{te boues olim nisi reddidisses \\ per dolum amotas puerum minaci \\ uoce dum terret, uiduus pharetra risit Apollo.}

Once when you were a boy Apollo, while scaring you in menacing tones if you wouldn't give back the cows taken by stealth, lost his quiver and laughed.

(Horace $C$. 1.10.9-12) punctured, and no more needs to be said about their reconciliation. This version was already in Alcaeus, and our hymnist knew of it. ${ }^{25}$ In the Homeric Hymn to Hermes, divine reconciliation again comes

\footnotetext{
${ }^{24}$ 363-4 263-4. See on this Thomas 2010: 216-20.

${ }^{25}$ Alcaeus fr. 308 Voigt, with Cairns 1983. This version of the story is briefly alluded to at H.Herm. 515 (cited below).
} 
through laughter, but rather than Hermes' quick fingers it is the thief's quick tongue and the persistent humour of the arbitration-scene that rob Apollo of his vestigial anger, for the moment.

Hermes also has good reason to accept Zeus's arbitration, even though it instructs him to lead Apollo to the cows. Indeed, he willingly submitted to an arbitration which he cannot have expected to absolve him. As we saw, Hermes' overriding ulterior motive is to make an Olympian début and get some prerogatives. He is thus very satisfied to have been publicly recognised as a son by Zeus, and as a herald and guide; and his speech doubtless impresses the other gods too.

\section{LIKE-MINDEDNESS BREEDS AFFECTION ${ }^{26}$}

Zeus's arbitration explicitly causes consensus. When Hermes and Apollo left for Olympus they were described as

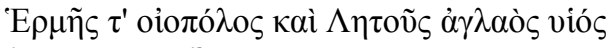

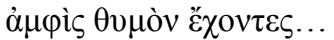

Hermes the shepherd and the treasured son of Leto, with diverging aims...

Afterwards (391-2):

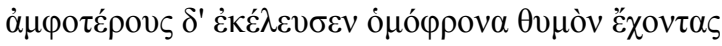

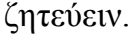

And he bid both sides to search with their hearts in sympathy.

The conflict of $\dot{\alpha} \mu \varphi i_{\zeta}$ is transmuted into the consensus of $\dot{\alpha} \mu \varphi \tau^{\prime} \tau \varepsilon \rho .^{27}$

The poet describes, however, the fragility of new-found like-mindedness. The pair head straight to the cave where the cows are hidden. As Hermes presents the cows to Apollo, the latter notices the skins of the two animals which Hermes killed, and immediately reverts to hostility. He attempts to bind Hermes with improvised ropes of agnus castus, implicitly so as to haul him back to Zeus for

\footnotetext{
${ }^{26}$ Democritus fr. 186 D-K ó

${ }^{27}$ For $\dot{\alpha} \mu \varphi \dot{c} \varsigma$ in such contexts cf. $\dot{\alpha} \mu \varphi \imath \sigma-\beta \eta \tau \dot{\varepsilon} \omega, \dot{\alpha} \mu \varphi \uparrow \lambda-\lambda \dot{\varepsilon} \gamma \omega$. Another linguistic marker of conflict and consensus in this part of H.Herm. is the use of balancing or juxtaposed formulas for Apollo and Hermes (214-15, 235-45,

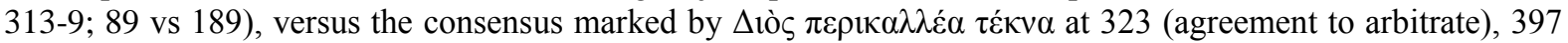
(agreement to return cows), 504 ( $\varphi \imath \lambda i ́ \alpha)$.
} 
prosecution. Hermes is able to magic these chains off his wrists and back into the earth, and Apollo's anger is overcome by wonder (414). The next lines, which contain a lacuna after 416 , may involve a second wobble. Hermes notices that the fire where he cooked the cows is still glowing; ${ }^{28}$ in the lacuna, Apollo probably noticed this too, and veered back to anger; finally, where the text resumes, Hermes 'soothes' him (417) by revealing the lyre, which he has been keeping up his sleeve for almost two hundred lines.

These two oscillations in Apollo's attitude, coming in scarcely over twenty lines at a much more jagged pace than we have had earlier in the hymn, not only show the shakiness of the brothers' relationship, but also make the unifying force of the lyre, when it is revealed, all the more striking. The sound of the lyre makes Apollo smile, marvel, rejoice, feel desire. From the first words of his response he implies a willingness to swap (437-8):

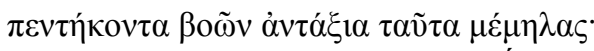

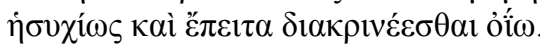

This interest of yours is well worth fifty cows. I rather think we will later reach a settlement peacefully.

Apollo also ends by circling back to this idea with promises of gifts (461-2). His claim $\dot{\varepsilon} \varsigma \tau \varepsilon \dot{\lambda}$ o

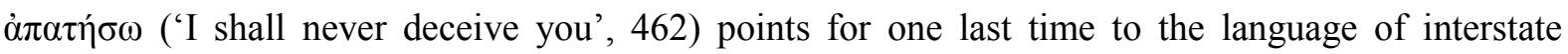
diplomacy, and in particular to contexts of alliance and confirmatory oaths. ${ }^{29}$ Hermes correctly interprets the implicit request, and this leads to the basic exchange, where Apollo gets the lyre and gives Hermes a cattle-prod and teaches him how to herd. ${ }^{30}$ The gods return to Olympus in shared pleasure (504-6).

\footnotetext{
${ }^{28}$ This interpretation of 415 (accepting Lohsee's $\dot{\alpha} \mu \alpha \dot{\alpha} \rho v \sigma \sigma o v$ ) allows the phrase $\pi \tilde{v} \rho \dot{\varepsilon} \gamma \kappa \rho v ́ \pi \tau \varepsilon ı v$ to retain its specific sense of concealing a fire under ashes. cf. Od. 5.488, Ar. Av. 841, Arist. Juv. 470a16, Sotades fr. 1.19, Thphr. Ign. 19. See, similarly, Clay 1989: 137 n. 133.

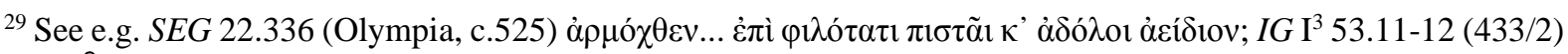

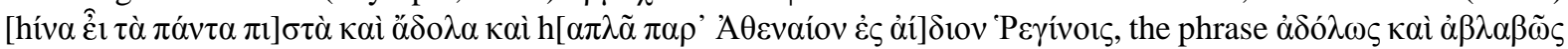

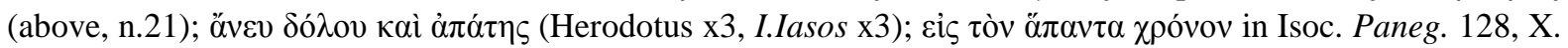
$H G$ 6.5.41 etc. For other diplomatic language see nn. 17, 21.

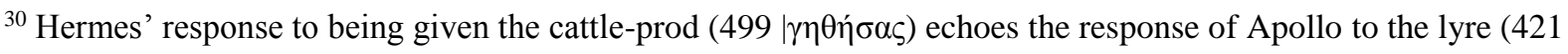

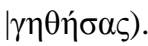


Immediately after this comes the hymn's final movement, which confirms the gods' mutual affection ( $\varphi \imath \lambda i \alpha)$. The whole passage is structured by three pairs of $\varphi \imath \lambda$ - words: ${ }^{31}$

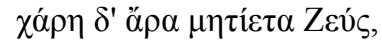

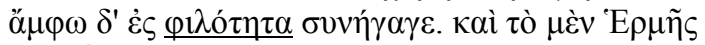

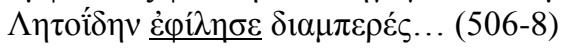 \\ And Zeus the planner rejoiced, and drew both together to affection. On the one side, Hermes cherished \\ the son of Leto continuously...
}

The lasting evidence for Hermes' $\varphi \imath \lambda i ́ \alpha$ for Apollo is the gift of the lyre and a pledge - at last, a reliable

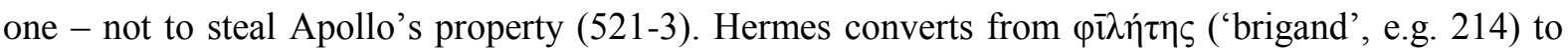

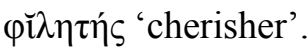

The transition at 524-5 then introduces Apollo's $\varphi \imath \lambda i ́ \alpha$ for Hermes:

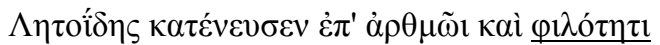

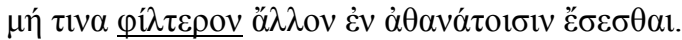

The son of Leto bowed his head to a condition of unity and affection, that among the immortals nobody else would be more cherished by him.

Apollo also swears to friendship, and offers further gifts which tie up Hermes' earlier concerns of wealth and prophecy, as expressed to his mother in 166-81 (with the emphasis on wealth, but a passing reference to Apollo's prophecy) and to Apollo after the revelation of the lyre (467-74, with the emphasis on prophecy, but a passing reference to Apollo's wealth). Thus Apollo offers Hermes a gold staff conferring wealth, immunity, and the power to fulfil Zeus' prophecies for good (528-32); subsequently he offers the mysterious prophetic Bee-maidens of Parnassus (550-67). ${ }^{32}$

Underlying this transition from the ópó $\varphi \rho \omega v \theta 0 \mu$ ó $\varsigma$ of 391 to $\varphi \imath \lambda i ́ \alpha$ is the double sense of

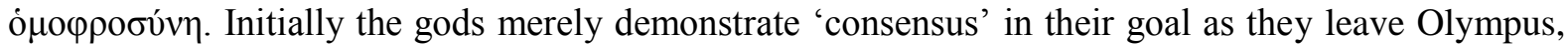
but as their friendship blossoms they achieve a fuller 'like-mindedness'. This is expressed in a rally of witticisms where the two gods co-operate to link Apolline prophecy and Hermetic lyre-playing. Apollo initiates this to-and-fro by describing the lyre's sound as an ö $\sigma \sigma \alpha$ in 443 , normally a prophetic

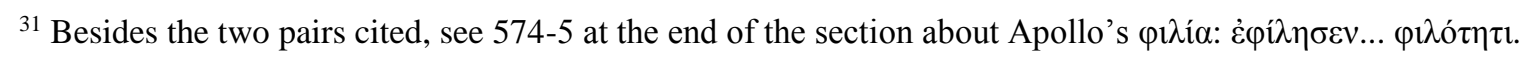

32 The best discussions of these are Scheinberg 1979, Larson 1995.
} 
voice or rumour. Hermes then describes how to play the lyre in $482-8$ as if it were a curious hybrid of Pythia and prostitute - a girl to stroke, but also one who 'teaches answers to questions', if one knows how to avoid the wrong question. Apollo deliberately echoes that when he describes Delphic and beemaiden prophecy (541-66). All three cases are delineated into the positive then the negative, using

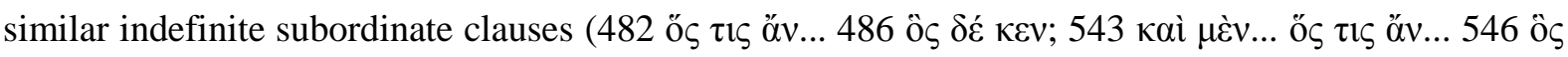

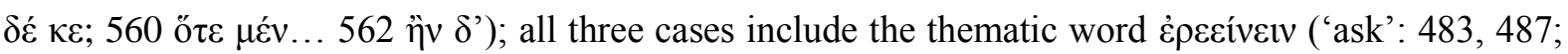
547; 564); and various words connect the three pairwise. ${ }^{33}$ Apollo describes the Delphic oracle as 'herding' humans (542 $\pi \varepsilon \rho \imath \tau \rho \pi \varepsilon \dot{\varepsilon} \omega v$ ) and willing to deceive them for profit (549). This is therefore a Hermetic Apollo - given Hermes' connection to deceit, profiteering, and his new-found role as a herder - and quite different from the Delphi depicted in the Homeric Hymn to Apollo.

\section{EXCHANGE AND TRANSFORMATION}

The first three sections of my chapter have indicated how the Hymn presents Hermes' motivation in initiating a conflict with Apollo enigmatically, then explores a gamut of methods of conflict-resolution, including self-help, shared linguistic and paralinguistic humour, shared gifts, a father settling a fraternal squabble, a formal private arbitration, and even language from interstate politics. The result is that Apollo and Hermes attain a close friendship and empathetic ó turn to reasons why the story is presented in this way. As I have mentioned, it is not the case that other versions of the myth are all similar: they do not - for example - contain an arbitration scene.

Norman Brown in 1947 suggested a way to explain the narrative via a historical conflict, namely a supposed class-struggle in Athens between artisans (represented by Hermes) and aristocrats (Apollo). Conceivably such an interpretation has a grain of truth to it, but even so it is profoundly underdetermined: it does not explain the poetic logic of why Hermes' initial motivation is revealed piecemeal, or why so many forms of reconciliation are alluded to, or why the humour is mostly verbal, and so on. My concern is to elucidate those literary questions. My interpretation is broadly historicist,

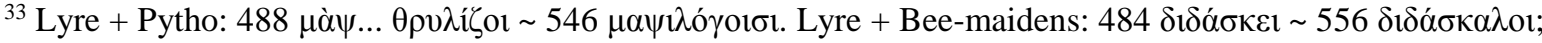

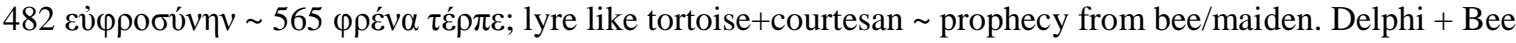

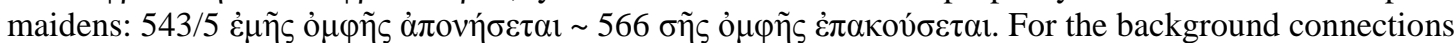
between lyre-playing, prophecy, and bees, see Scheinberg 1979.
} 
but whereas Brown wanted to tie the Hymn to a particular external conflict, my approach aims to understand why the poetics of conflict and consensus were effective to deploy in the context of performing a hymn to Hermes in a given period.

The story of a god's birth and introduction to Olympus was favoured in Greek hymnography, and Jenny Strauss Clay has influentially identified a tendency for the Homeric Hymns to concern themselves with how the gods received their familiar prerogatives (and sometimes some less familiar ones too).$^{34}$ Our hymnist chose to accept this trope, and in particular to present Hermes' meteoric rise in status from being a secretive love-child in the sticks, who has to pull himself up by the sandal-straps using his characteristics (cunning, thievery, bargaining) to literally carve out some prerogatives for himself. This is the Hermes whose inventiveness adds value to a tortoise, and who then swaps his invention for a big profit. This is the god of trade and of exchanges. As Apollo says (516-17):

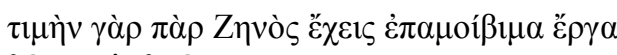
$\theta \eta \dot{\sigma} \sigma \varepsilon v \dot{\alpha} v \theta \rho \dot{\pi} \pi \mathrm{ol \sigma}$.

For you have from Zeus the honour that you will lay down the business of interchange for men.

This general character of Hermes both explains and is foretold by his modes of conflict-resolution - his recourse to rhetoric and humour, and the give-and-take of justice in arbitration. Perhaps the most impressive of his several acts of conversion is the change he effects in Apollo's attitude, so that he willingly adapts his identity and plays up to a new 'Hermetic' character to demonstrate like-mindedness.

The story could have been handled differently, and its design brings out certain major qualities in the god, a procedure whose accuracy ensures an appealing and effective hymn. Contrast the similar set-up of the Homeric Hymn to Apollo, where again a new-born god has to get some honours:

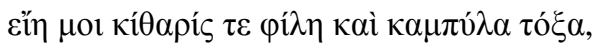

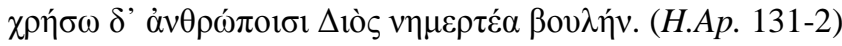

May the lyre and curved bow be dear to me, and I shall foretell Zeus' unerring plan to humankind.

\footnotetext{
${ }^{34}$ Clay 1989. It is, however, difficult to find this strand in H.Aphr. or H.Dion.
} 
Apollo innately knows the future - that is one of his characteristics - and straight after his birth can declare a pre-existing right to various objects.

In fact, the contrast with the Hymn to Apollo is not of merely heuristic value in drawing attention

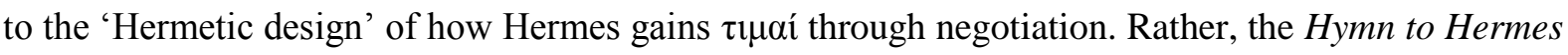
shows a deep-seated engagement with its predecessor. My main focus here is how Apollo's first moments (H.Ap. 119ff.) are each redeployed in the Hymn to Hermes, with a coherent programme. This is summarised in Table 1 below.

In many cases, we get a strong sense of one-upmanship: the Hymn to Apollo exaggerated Apollo's precocity, whereby he has instant knowledge of bow and lyre. The Hymn to Hermes responds with similar exaggeration by making Hermes an infant rather than the youth he is in many other sources, and by having Hermes reprise the areas of Apollo's precocity to Apollo's detriment. ${ }^{35}$ Thus Apollo undergoes a baby-routine of being washed and swaddled, but is fed nectar and ambrosia instead of milk (H.Ap. 120-5). At H.Herm. 267-8, Hermes refers to a baby-routine as part of his عikós-argument against Apollo; on the question of food, he cooked two of Apollo's cows because of his unconventional hunger. Apollo bursts through his swaddling (H.Ap. 127-9), whereas Hermes reworks his swaddling as part of his disguise against Apollo (H.Herm. 235). ${ }^{36}$ Related to this are the 'chains' of agnus castus which Apollo applies to Hermes at 409 - Hermes does not burst through them, but constructively recycles them to grow spontaneously in the earth. The revitalisation belongs with the trope of earth flowering at an 'epiphany', a notable example of which is Delos' sudden flowering underfoot when Apollo is born (H.Ap. 135-6). But in the Hymn to Hermes, it is Apollo himself who is astonished. Finally, two of

\footnotetext{
${ }^{35}$ Hermes invents lyre when older: D.S. 5.75.3; perhaps also in Metiochos and Parthenope, though that has been mediated through a Persian source where 'Hurmuz' was not a god (Hägg \& Utas 2003: 106-13, 232-4). Steals cows when older: Ant. Lib. $23 \sim$ Ov. Met. 2.683-707; $\Sigma$ Nic. Alex. 260 (during Admetus' lifetime); LIMC Hermes \#245-8, Apollo \#1041 (assuming that these do depict Hermes and Apollo's cattle).

The parallels which follow have mostly been in the public domain since Dornsieff 1938 (for a recent survey see Vergados 2013: 70-3); my aim here is to explain why the poet deployed them. I thank Adrian Kelly and Bruno Currie for advice offered when I first made the following argument, in Oxford back in November 2006.

${ }^{36}$ He uses the swaddling both to look like a normal (hence innocent) baby and to hide the lyre.
} 
Apollo's precocious activities are speaking as soon as he is born, and setting off from Delos to Olympus; Hermes is a more cunning walker and speaker, and uses both against Apollo. ${ }^{37}$

On these aspects of the story, the guiding principle is one-upmanship. More compromise is discernible regarding the lyre, the bow, and prophecy. The Hymn to Hermes firmly reappropriates the lyre for Hermes: Apollo declares emphatically that he has never seen one before (443-5), and therefore cannot have demanded it at his birth. On the other hand, Apollo does end up keeping the lyre. Apollo's bow is worked into the Hymn to Hermes only at 515, where Apollo fears

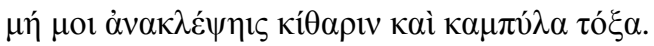
that you will steal my lyre and curved bow.

By this stage of the hymn, Hermes is co-operating, so Apollo's bow is safe. The fact that the collocation

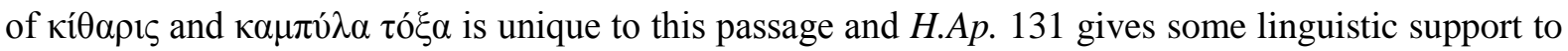
my claim of a systematic intertextual relationship.

The most complex engagement is the Hymn to Hermes' depiction of prophecy, whose large role - when Hermes is not a great god of prophecy - is conditioned by the large role of Apollo. In an antagonistic opening phase, Hermes wants a share in Apollo's prophetic prerogatives, then Apollo sees a bird-omen (213) which does not help him find his cattle, and is echoed ridiculously by Hermes' fart, described as an 'auspice' (294-6). In the conciliatory phase of the hymn, however, Hermes gets only a subordinate prophetic skill on Parnassus, where he is following in Apollo's footsteps (556-7), rather than making Apollo track him as he had in the earlier part of the hymn. However, as we saw, Apollo

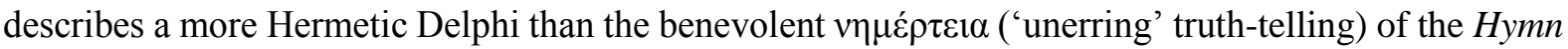
to Apollo.

\section{<INSERT TABLE 1 HERE IF POSSIBLE>}

Table 1: The Hymn to Hermes reworks Apollo's first moments

$$
\text { H.Ap. } 119 \mathrm{ff} .
$$

H.Herm.

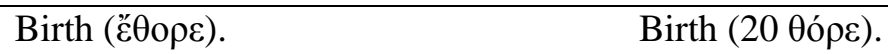

\footnotetext{
${ }^{37}$ On the walking of Hermes and Apollo see Detienne 1997, esp. p. 11.
} 
Washed, swaddled. Fed not on milk

but on nectar and ambrosia.

Bursts through swaddling and bands;

Delos flowers with gold.

Goddesses marvel at Apollo.

Walks.

Declares interest in...

lyre,

bow,

prophecy.
Deception (267-8): babies like me like being washed and swaddled, and mother's milk. (In fact, Hermes was hungry for meat.)

Keeps swaddling for disguise. Does not burst vitex (409) but makes it reroot spontaneously. Apollo marvels at Hermes. Walking, which makes Apollo’s step flustered. Precocious speech used against Apollo. Hermes invents lyre (cf. esp. 443-5).

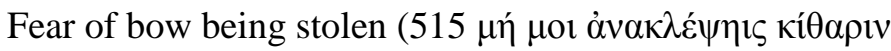

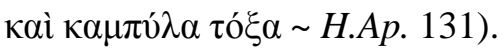
Apollo's prophecy at first in bad shape; then Hermes accepts subordinate position and Apollo presents Delphi rather 'Hermetically'.

What emerges from this sketch, to which one could add further details, is that the conflict and consensus of the two hymns mirror the conflict and consensus within the Hymn to Hermes between Hermes and Apollo. ${ }^{38}$ The issue of prophecy is particularly emblematic, whereas other issues focus more on either conflict or consensus. This metapoetic reading is supported by the fact that Hermes is a patron of music who sings an inset hymn with a rather similar start to the outer hymn (54-61, where 578 recalls 3-4). Moreover, Hermes is an ambitious latecomer who thieves from his elder brother with ulterior motives - a suitable and familiar trope in the discourse by which poets signal their engagement with their predecessors. ${ }^{39}$ Horace calls Mercury

callidum quicquid placuit iocoso

\footnotetext{
${ }^{38}$ Further points about the relationship of the two hymns can be made about the treatment of Onchestos, some minor verbal echoes, and further areas where the gods take different approaches to the same 'problem' (e.g. firestarting).

${ }^{39}$ I have found Hinds 1998 and Ricks 2002 particularly helpful on such matters.
} 
condere furto.

(C. 1.10.7-8)

clever at hiding anything you have chosen in jesting theft.

Hermes commits 'playful theft' from Apollo, while Horace commits to papyrus (condo also means 'compose': TLL s.v. II.D) a playful borrowing of the story of Alcaeus' Hymn to Hermes.

We can apply this general metapoetic idea to how the Hymn to Hermes presents lyre music. Lyre-music is not just 'lovely', but strikingly eroticized: the tortoise and lyre are both like a courtesan; ${ }^{40}$ the lyre's sound repeatedly causes desire when Apollo first hears it. ${ }^{41}$ Whereas Apollo's lyre often twangs like a bow, Hermes' lyre belongs with courtesans, wine, and jokes, i.e. with the symposium. ${ }^{42}$ This connection is made explicit twice, in each instance with specific reference to Hermes' singing:

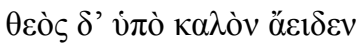

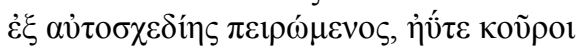

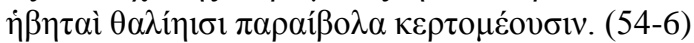

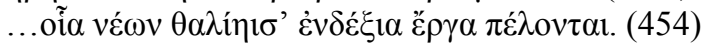

And the god made trial extempore and sang to it well - as youths in their prime make bantering(?) retorts at festivities. $^{43}$

...like the business which moves round to the right at young men's feasts.
}

The reference is to improvised and ribald catches which went round the room at some symposia - here specifically a symposium for young men. ${ }^{44}$ Yet Hermes' songs are essentially a hymn to his parents and a theogony. These may seem to be as far removed generically as one can get from such $\dot{\varepsilon} v \delta \varepsilon \dot{\varepsilon} \xi 1 \alpha$ हैp $p \alpha$ :

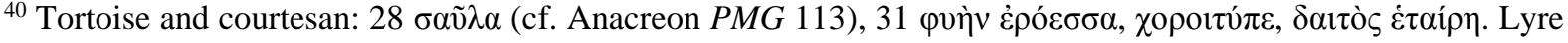
and courtesan: 478-86 (discussed further below).

41 421-3, 426, 434, 447, 449, 455.

${ }^{42}$ For lyre-playing courtesans at Attic symposia see Peschel 1987 nos. 8, 40, 151, 194-6, 198, 203; Ath.Pol. 50.2 (with Rhodes 1981). Other particular emphases in H.Herm.'s portrayal of music include a focus on inventiveness against birthright, and on practice against the model of musicality as a divine gift (cf. 448, 485, against Apollo's assumption in 440-2; compare Prot. fr. 10, Anaxag. fr. 21b).

${ }^{43}$ Given the range of $\pi \alpha \rho \alpha \beta \alpha \dot{\lambda} \lambda \lambda \omega, \pi \alpha \rho \alpha i \beta \beta o \lambda \alpha$ could mean 'rejoining', 'vying in words', 'cast sideways' (cf.

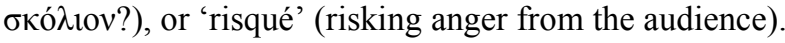

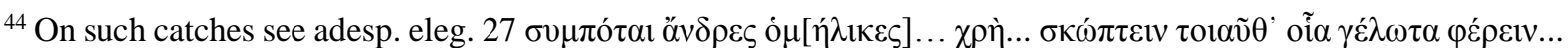

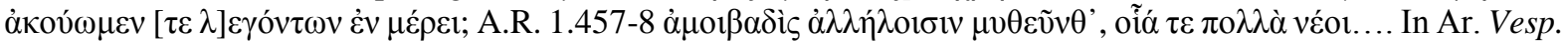
1222-49, Philocleon trains Bdelycleon for a symposium of witty and apt 'capping' where one traditional song is continued by another; Bdelycleon's rude responses are 'incorrect' in Philocleon's terms, but match the kind of banter envisaged in H.Herm. For competitive but not rude capping see also PMG skolia 10, 12, 13 (on Harmodius

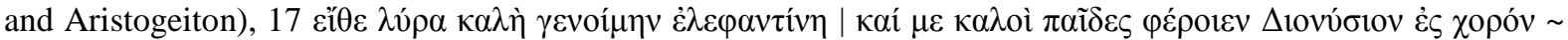

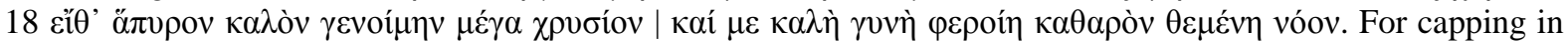
Certamen see Bassino's chapter. Hermes stands on Apollo's left (424), precisely so that he can hand on the lyre 'to the right'.
} 
this is one of Hermes' 'lyre's paradoxes'. However, Hermes and Apollo are indeed like sparring youths, and as we have seen the Hymn to Hermes itself - a hymnic and theogonic performance - is too: it caps a previous poetic performance (the Hymn to Apollo) in a fundamentally jocular and resolvable piece of

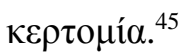

So far I have taken separately Hermes' mastery of exchanges (including his negotiation from conflict to consensus with Apollo) and the hymn's transformation of the Hymn to Apollo (its conflict and 'reconciliation' with it). But they are inseparable. The hymnist worships Hermes' transformative imagination by reperforming it on the materials of hymnic tradition: this is why allusion to the Hymn to Apollo is valuable for the hymnist. It is also against this background that the hymn's uses of paradox and riddle seem to make the best sense. By being forced to face and resolve cognitive dissonance, the audience come to understand 'from the inside' the imagination of the eponymous master of hermeneutics. And so - finally - I return to the earlier question of why Hermes' initial motivation has to be puzzled out slowly. The resolution of ambiguity and conflicting interpretations transposes onto the level of hermeneutics the hymn's Hermetic preoccupation with conflict and reconciliation. ${ }^{46}$

Hermes and Apollo are brothers, at once the closest reciprocal relationship, and the one which time and again Greeks mention in contexts where it has broken down. ${ }^{47}$ Despite exceptions (like Teucer and Ajax), half-brothers are particularly liable to quarrel. The characters of Euripides' Hippolytus repeatedly assume that Hippolytus and Phaedra's children are rivals (E. Hipp. 309, 962-3, 1010). The chorus deprecates ménages à trois at Andromache 465-7:

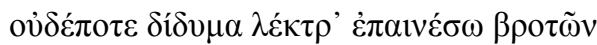

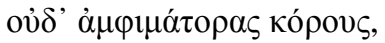

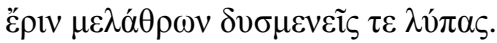

Never shall I praise a mortal's double sex-life, nor sons of different mothers - a strife to the household, and hateful source of pain.

\footnotetext{
${ }^{45}$ For $\kappa \varepsilon \rho \tau$ o ${ }^{\prime} \alpha$ as a potentially consensual form of conflict, cf. Hesk's chapter.

${ }^{46}$ Similarly, the audience must gradually figure out why the tortoise is sexy (n. 43), which becomes clearer only when Hermes has made it into a lyre and brought it closer to the world of courtesans.

${ }^{47}$ Cf. Canevaro in this volume, and Loraux 2002: 197-228; also Ogden 1996: 188-99, who discusses several of the following examples.
} 
Cleomenes declares himself in Herodotus 5.72 to be more Achaean than Dorian, which cannot have sat well with his half-brother 'Dorieus'. In Antiphon 1, a man prosecutes his stepmother while his halfbrothers defend. Finally, and at greatest length, we have the complex machinations of Boiotos against his half-brother Mantitheos, as presented in Demosthenes 39-40. ${ }^{48}$

Hermes and Apollo, however, manage to become best of friends, and to share out both possessions and character-traits. This had to be, theologically, and in particular if - as I believe - the hymn was designed for a performance at Olympia. ${ }^{49}$ Hermes sought shared honours in a Dodecatheon, as expressed in his carving. And indeed, in the Dodecatheon at Olympia he shared an altar with none other than Apollo, as Herodorus tells us (FrGH $31 \mathrm{~F} 34 \mathrm{a})$.

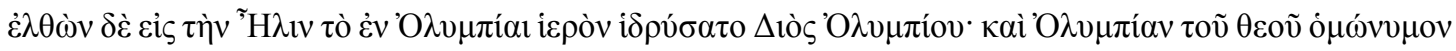

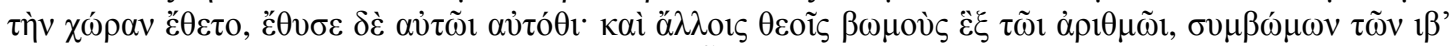

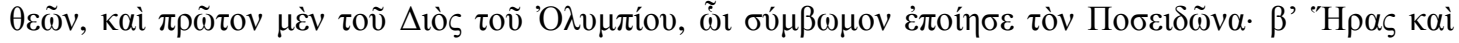

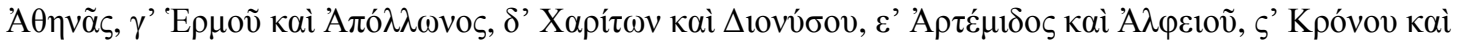
'Ṕ́as.

When [Heracles] came to Elis he founded the sanctuary in Olympia of Olympian Zeus (he also named the place Olympia after the god, and sacrificed to him there), and for the other gods he founded the altars, six in number, of the 12 altar-sharing gods - the first belonging to Olympian Zeus, whose sharer he made Poseidon, the 2nd to Hera and Athena, the 3rd to Hermes and Apollo, the 4th to the Graces and Dionysus, the 5th to Artemis and the Alpheus, and the 6th to Kronos and Rhea.
\end{abstract}

We have thus seen various factors which shaped the Hymn to Hermes' presentation of the issues dealt with in this volume: Hermes' involvement in negotiation and decryption; the hymn's intertextual project as a means for the hymnist not only to characterise both protagonists but also to show that he had internalised Hermes' transformative powers; Greek ideas of sibling rivalry; and perhaps the Hymn to Hermes' performance setting, where Hermes and Apollo shared an altar. The hymnist's response to these factors has produced for us a thoroughgoing examination of familial conflict, forms of conciliation, and degrees of consensus.

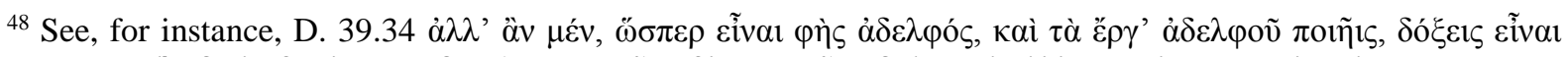

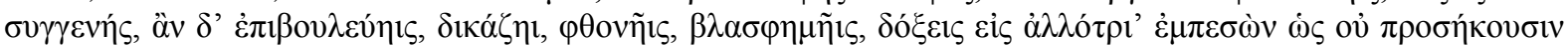
ov์ $\tau \omega \chi \chi \tilde{\eta} \sigma \theta \alpha 1$. 'But if, just as you claim to be my brother, you also act like a brother, you will seem to be related. If however you plot, sue, envy, and denigrate me, you will seem to have fallen upon another's property and to be using it as if it had no connection to you.'
}

${ }^{49}$ See Burkert 1983, Thomas forthcoming. 



\section{Bibliography:}

Brown, N. O. (1947) Hermes the Thief. Madison, Wisc.

Burkert, W. (1983) 'Sacrificio-sacrilegio: il “trickster" fondatore', StudStor 25: 835-45, reprinted in Riedweg C. ed. (2001), Walter Burkert: Kleine Schriften vol. I: Homerica. Göttingen.

Cairns, F. (1983) ‘Alcaeus’ Hymn to Hermes, P. Oxy 2734 Fr. 1 and Horace Odes 1,10', QUCC 42: 2935.

Clay, J. S. (1989) The Politics of Olympus. Princeton.

Cohen, D. (1983) Theft in Athenian Law. Munich.

Detienne, M. (1997) 'This is where I intend to build a glorious temple' (transl. J. Lloyd), Arion 4: 1-27.

Dornsieff, F. (1938) 'Zum homerischen Hermeshymnos', RhM 87: 80-4.

Glotz, G. (1904) La Solidarité de la famille dans le droit criminel en Grèce. Paris.

Görgemanns, H. (1976) 'Rhetorik und Poetik im homerischen Hermeshymnus', in Studien zum antiken Epos, Franz Dirlmeier und Viktor Poeschel gewidmet, eds. H. Görgemanns and E. A. Schmidt. Meisenheim: 113-28.

Hägg, T. and Utas, B. (2003) The Virgin and her Lover: Fragments of an Ancient Greek Novel and a Persian Epic Poem. Leiden.

Hansen, M. H. (1976) Apagoge, Endeixis and Ephegesis against Kakourgoi, Atimoi and Pheugontes. Odense.

Hinds, S. (1998) Allusion and Intertext. Cambridge.

Kahn, L. (1978) Hermès passe, ou les ambigü̈tés de la communication. Paris.

Larson, J. (1995) 'The Corycian nymphs and the bee maidens of the Homeric Hymn to Hermes', GRBS 36: $341-57$.

Long, C. R. (1987) The Twelve Gods of Greece and Rome. Leiden.

Loraux, N. (2002) The Divided City (transl. Pache, C. and Fort, J.). New York.

Ogden, D. (1996) Greek Bastardy. Oxford.

Parker, R.C.T. (1983) Miasma. Oxford.

Peschel, I. (1987) Die Hetäre bei Symposium und Komos in der attisch rotfigurigen Malerei des 6.-4. Jhs. v.Chr. Frankfurt. 
Renehan, R. (1981) 'The Greek anthropocentric view of man', HSCP 85: 239-259.

Rhodes, P. J. (1981) A Commentary on the Aristotelian Athenaion Politeia. Oxford.

Ricks, C. (2002) Allusion to the Poets. Oxford.

Roebuck, D. (2001) Ancient Greek Arbitration. Oxford.

Scheinberg, S. (1979) 'The bee maidens of the Homeric Hymn to Hermes', HSCP 83: 1-28.

Sowa, C. A. (1984) Traditional Themes and the Homeric Hymns. Chicago.

Thomas, O. R. H. (2010) ‘Ancient Greek awareness of child language acquisition', Glotta 86: 185-223. (forthcoming). 'Sacrifice and the Homeric Hymn to Hermes 112-41', in Animal Sacrifice in the Ancient Greek World, eds. S. S. Hitch and I. C. Rutherford. Cambridge.

Vergados, A. (2013) The Homeric Hymn to Hermes: Introduction, Text and Commentary. Berlin.

West, M. L. (2001) 'The fragmentary Homeric Hymn to Dionysus', ZPE 134: 1-11. 